\title{
Ecological Civilization and Legal Norms for Resilient Environmental Governance
}

\author{
Nicholas A ROBINSON \\ University Professor on the Environment and Gilbert and Sarah Kerlin \\ Distinguished Professor of Environmental Law Emeritus; Pace University, \\ Elisabeth Haub School of Law, New York, NY, USA \\ nrobinson@law.pace.edu
}

\begin{abstract}
The aim of this article is to examine how the principles of ecological civilization can help shape a consensus about restating environmental legal principles generally. This restatement is essential given the fact that many human laws have proven to be manifestly at variance with the natural systems of Earth's biosphere. Disruptions caused by climate change increase and the sixth great extinction of species has ushered in crises in biodiversity. It is argued that with environmental degradation becoming worse world-wide, more is required of governments than just again endorsing steps to advance sustainable development. Rather, there is a need for more effective and resilient governmental management. States must agree upon the progressive development of the law necessary to deal with Earth's changing, new, and real conditions. New environmental principles, such as the principle of resilience, will need to be added to the existing ones. Potentially, China can contribute greatly to the global debate about Earth's ecological law principles by sharing its knowledge and understanding of ecological civilization.
\end{abstract}

\section{Keywords}

ecological civilization - ecological law - sustainable development - Sustainable Development Goals - environmental principles - principle of resilience environmental governance 


\section{Introduction: Exploring Legal Dimensions of Ecological Civilization}

The Earth is home to perhaps two billion species of plants and animals, with scientists discovering new species every year. ${ }^{1}$ Humans number seven and a half billion today, and we may be ten billion by the middle of this century. To ensure that humans can co-exist sustainably with other species, all nations have been progressively adopting environmental laws and programs for conservation of nature, ${ }^{2}$ beginning with the 1972 UN Stockholm Conference on the Human Environment. States agreed on the Stockholm Declaration, ${ }^{3}$ basic principles to begin cooperating internationally to protect Earth as the common home for humankind. ${ }^{4} 1992$ marked an extraordinary advance at the United Nations Conference on Environment and Development ('UNCED', also known as the Earth Summit) in Rio de Janeiro, where nations adopted Agenda 21 by consensus. ${ }^{5}$ Agenda 27 is a plan for ensuring sustainable development, and its Chapter 8 called on nations to further develop their national environmental laws. ${ }^{6}$ UNCED also adopted the Rio Declaration on Environment and Development, with its set of principles by which governments could ensure sustainable socio-economic and ecological development. ${ }^{7}$

Although most nations have implemented many of the Rio Declaration principles, Earth's natural environmental systems continue to decline. In 2015, the UN General Assembly adopted the United Nations' Sustainable Development Goals (SDGs), ${ }^{8}$ which include environmental law objectives ${ }^{9}$

1 SUNY College of Environmental Science \& Forestry Lists Top 10 New Species for $2017<$ https:// phys.org/news/2017-05-esf-species.html>.

2 L KULAKULASURIYA, and NA ROBINSON, 'Training Manual on International Environmental Law' (UN Environment Programme, 2006), available at <https://digitalcommons .pace.edu/lawfaculty/791/>.

3 Stockholm Declaration on the Human Environment, UN Doc.A/CONF 48/14.

4 Report of the United Nations Conference on the Human Environment, 5-16 June 1972, A/CONF.48/14/Rev.1, at <http://un-documents.net/aconf48-14r1.pdf>.

5 United Nations Conference on Environment \& Development, 3-14 June 1992, 'Agenda 21', A/CONF. 151/L.3/Add. 111 June 1992, available at <https://sustainabledevelopment.un.org/ content/documents/Agenda21.pdf>.

6 ibid 8.13-8.26; see also NA ROBINSON (ed), 'Agenda 21: Earth's Action Plan,' (Oceana Publications, New York, 1993).

7 Rio Declaration on Environment and Development, United Nations General Assembly, A/151/26 (vol 1) at <https://www.un.org/en/development/desa/population/migration/gener alassembly/docs/globalcompact/A_CONF $>$. <151_26_Vol.I_Declaration.pdf > .

8 Transforming our World: the 2030 Agenda for Sustainable Development UNGA 70/1, 21 October 2015.

9 In particular SDG 16.3: 'Promote the rule of law at the national and international levels and ensure equal access to justice for all', ibid. 
and are intended to reverse this decline and accelerate socio-economic progress. But implementation of the Goals lags. ${ }^{10}$ As the world approaches the 5oth anniversary of the Stockholm Conference, can States agree on a new set of legal principles to build resilience and effectiveness into implementation of the SDGs? What might be agreed in a next international, intergovernmental declaration of the principles?"1 Can such a declaration guide nations to cooperate through a transition into global ecological civilization? ${ }^{12}$ To examine this question, it is instructive to explore five interrelated issues: (a) why Earth's ecological plight requires action; (b) how innate, human affinities for nature can build consensus or restoring Earth's natural systems; (c) why international environmental law alone is insufficient to reverse global ecological disruption trends; (d) what principles of law might serve to enhance transition to an 'ecological civilization'; and (e) as a case study, what benefits recognizing the legal principle of resilience might serve.

\section{Humankind's Declining Ecological Home}

In all regions it has become evident that Agenda 21 and the Rio Declaration have not been effective enough in halting environmental degradation. For example, North America faces an ecological crisis. Human development is progressively crowding out other species, with their numbers decreasing perceptively. The American Association for the Advancement of Science reports that human activity has 'contributed to a thousand-fold increase in global extinctions ... compared to the presumed pre-human background rate. ${ }^{\prime 3}$ For instance, in the past five decades, in North America has experienced a loss of

10 See the United Nations 'Sustainable Development Goals Report' (2019) on implementation of the SDGs for 2019, <https://unstats.un.org/sdgs/report/2019/>.

11 The United Nations General Assembly has mandated consultations to examine the possibilities for such a political declaration. See 'Follow-up to the report of the ad hoc open-ended working group established pursuant to General Assembly Resolution 72/733,' UN General Assembly Resolution A/RES 73/333 (4 September 2019) < https://undocs.org/ en/A/RES/73/333>.

12 Ecological Civilization is still an evolving conceptual framework. As HANSON notes, 'Ecological civilization is being used by the People's Republic of China (PRC) to provide a coherent conceptual framework for adjustments to development that meets 21st century challenges', Arthur Hanson, Abstract for 'Ecological Civilization In the People's Republic of China: Values, Action and Future Needs', Asian Development Bank (ADB) East Asia Working Paper Series, No. 21, December 2019.

13 KV ROSENBERG, et al, 'Decline in North American Avifauna,' Science, vol 366, issue 6461, 120 (4 Oct. 2019). 
three billion birds, which represents a $29 \%$ loss of the abundance of the avian species that were known in that region in 1970. ${ }^{14}$

The United Nations Environment Programme's Sixth Global Environmental Assessment (GEO-6) confirms that comparable regional experiences are found everywhere on Earth. ${ }^{15}$ The trends are alarming. Humans today are living through the sixth great extinction of species, which scientists have termed a 'biological annihilation.16 The earlier extinctions were not caused by human activity. This one is, and not just in North America but world-wide, as the Species Survival Commission of the International Union for the Conservation of Nature (IUCN $)^{17}$ has been reporting for decades.

GEO-6 presents all Earth's natural systems as interrelated. ${ }^{18}$ What happens in one place affects other parts of the planet. Other reports elaborate these interactions, such as the United Nations-sponsored Intergovernmental Panel on Climate Change (IPPC), revealing how all Earth's systems interact. In 2019 under the auspices of the IPCC, 100 scientists from 36 countries evaluated 7,0oo scientific publications to prepare a special report released in late 2019, 'On the Oceans and Cryosphere in a Changing Climate.'19 The analysis reveals that oceans have absorbed as much as $30 \%$ of the carbon dioxide released since the 1980s, causing ocean acidification. This disrupts the food chain and conditions of life for many marine species, when marine resources are already under stress. The marine fishing industry extracts many types of fish beyond their reproductive capacity. Despite the work of regional treaty organizations to protect marine species, fish stocks continue to decline. Human

14 ibid.

15 GEO-6 (4 March 2019) <https://www.unenvironment.org/resources/global-environment -outlook-6>.

16 G CEBALLOS, et al, 'Biological annihilation via the ongoing sixth mass extinction signalled by vertebrate population losses and declines,' PNAS July 25, 2017114 (30) E6089E6o96 <https://doi.org/10.1073/pnas.1704949114>.

17 See generally Species Survival Commission, IUCN <https://www.iucn.org/commissions/ species-survival-commission/about>.

18 GEO-6 ( $\mathrm{n}$ 15) reports: 'Providing a decent life and well-being for nearly 10 billion people by 205 , without further compromising the ecological limits of our planet and its benefits, is one of the most serious challenges and responsibilities humanity has ever faced. People worldwide rely on the smooth functioning of Earth's natural life-support systems, in different ways and in different contexts. A healthy planet is a necessary foundation for the overall well-being and further advancement of humanity'; GEO-6, Introduction, Chapter $1<$ https://www.cambridge.org/core/services/aop-cambridgecore/content/view/ CE220oF7AC9FCAE27oAo55Co36A29A65/9781108627146c1_p2-19_CBO.pdf/introduc tion_and_context.pdf>.

19 IPPC 'Special Report on Oceans and Cryosphere in a Changing Climate,' (September 2019) at <https://www.ipcc.ch/srocc/chapter/summary-for-policymakers/>. 
'conservation' endeavours have not produced a 'sustained yield.' In addition, deteriorating ocean conditions imperil coral, shellfish, marine mammals and fish, not to mention the marine phytoplankton, which provide more than $50 \%$ of Earth's oxygen. ${ }^{20}$

The warming of the atmosphere is causing the melting of the Earth's glaciers and polar ice caps. Along with thermal expansion of ocean water molecules, relative sea levels will rise by at least one meter by $2100 .{ }^{21}$ This is 'baked in' and cannot be prevented. Impacts on seacoasts will be acute. The 'once-in-a100 -year' flooding from a storm surge will, by 205 , probably be an annual event. ${ }^{22}$ It is entirely possible that melting of the West Antarctic Ice Sheet and Greenland's glaciers will raise the sea levels by several metres. ${ }^{23}$

Another global scientific collaboration formed via the United Nations in 2012, the Intergovernmental Science-Policy Platform on Biodiversity and Ecosystem Services (IPBES), has assessed global changes. In 2019 IPBES reported that one million animal and plant species are threatened with extinction. ${ }^{24}$ For example, the survival of frogs and other amphibian species is in great danger. Loss of species is probably worse than we can document. Our scientific knowledge today includes only about 1.5 million species. ${ }^{25}$ Many more species exist, but we are ignorant about how we are impacting most of these species. Our human bodies, both in our intestines and on our skin, are host to millions of individual micro-organisms. The normal body flora helps to protect us from becoming infected with harmful microbes. ${ }^{26}$ Species are of course found at all scales. Rather than ignore species, we need proactively to sustain them, for their sakes and ours.

20 National Ocean Service, 'How much oxygen comes from the ocean?' < https://oceanservice .noaa.gov/facts/ocean-oxygen.html\#: :text=At\%2oleast\%2ohalf\%2oof\%2oEarth's\%2o oxygen $\% 2$ ocomes $\% 2$ ofrom $\% 2$ othe $\% 2$ oocean.\&text=Scientists\%2oestimate $\% 20$ that $\% 2050 \% 2 \mathrm{D} 8$ o,some\%2obacteria\%2othat\%2ocan\%2ophotosynthesize >.

21 IPCC 'Global Mean Sea Level Rise Projections' in Ch 13, Sea Level Change 2018.

22 Paul VOOSEN, 'Warming Transforms the oceans and poles,' Science, vol 365, issue 6460 (27 September 2019), at 1359 .

23 National Snow and Ice Data Center, <https://nsidc.org/cryosphere/quickfacts/icesheets .html\#: :text=Ice\%2osheets\%2ocontain\%2oenormous\%2oquantities,6o\%2o meters\%20(200\%2ofeet)>.

24 IPBES <https://www.ipbes.net/global-assessment-report-biodiversity-ecosystem -services>.

25 Brendan B LARSEN et al, 'Inordinate Fondness Multiplied and Redistributed: the Number of Species on Earth and the New Pie of Life,' The Quarterly Review of Biology (2017). DOI: $10.1086 / 693564$.

26 Microbiology on line, <https://microbiologyonline.org/about-microbiology/microbes -and-the-human-body>. 
However, as with the acute decline in different species of birds, impacts on many species are not well understood. Human governmental systems tend to ignore the relationships among species. For example, many governments are not careful about epizootic diseases, which humans share with wild and domesticated animals. The CoviD-19 pandemic further underscores the consequences if we fail to maintain healthy habitats. Wild animals are host to myriad viruses and bacteria. When human activity disrupts their habitat, they shed these microbes, which seek out new hosts. Through zoonosis, they infect humans, and diseases result. ${ }^{27}$ Diseases like CoviD-19, Avian influenza, Ebola and HIV-1/AIDS might have been kept in the wild animal world, but our activities released them on to humans. There is very little collaboration between veterinary science, medicine and public health, and nature conservation. As warmer weather allows mosquitos to live in northerly climes, they spread Zika and other diseases. Most countries lack a holistic, integrated and ecologically premised policy framework for preventing such zoonotic diseases. ${ }^{28}$

These environmental problems are, of course, aggravated by the impacts of climate change. The 'basics' of climate change are well known. Earth's atmosphere supports life itself, as opposed to the 'air' on Venus or Mars, because water vapor and carbon dioxide retain solar radiation and provide a harmoniously balanced biosphere, rich in oxygen renewed by the photosynthesis of our flora. Earth moves the heat from the tropics to the poles and back, through great patterns of ocean currents and winds. As the atmosphere has warmed, the air holds more water vapour, added by evaporation and transpiration from plants. With our clouds holding more water vapour, the volume of precipitation in rain or snow is greater than in the past. This leads to new levels of flooding. The warmer air also interacts with still-cold ocean surfaces, leading to more intense storms. As Earth's wind patterns change, so does Earth's hydrologic cycle, with new extremes of droughts or floods.

Human activities have warmed the Earth's atmosphere by $1^{\circ}$ Celsius since before the Industrial Revolution. In 2013, the concentration of carbon dioxide in the atmosphere passed 400 parts per million $(\mathrm{ppm}) .{ }^{29}$ Analysis of trace atmo-

27 Nicholas A ROBINSON and Christian WALZER, 'How do We Prevent the Next Pandemic', Scientific American (March 25, 2020) <https://blogs.scientificamerican.com/observations/how-do-we-prevent-the-next-outbreak/>; see also Nicholas A ROBINSON, 'The Next Pandemic Is Here', The Environmental Law Forum, November-December 2020, 30. See who, FAO, OiE Tripartite Guide to Addressing Zoonotic Diseases in Countries (2019) $<$ https://healthpolicy-watch.news/trilateral-guide-to-preventing-spread-of-animal -human-diseases/>.

29 'Climate Milestone: Earth's $\mathrm{CO}_{2}$ Level Passes 400 ppm', National Geographic <https:// www.nationalgeographic.org/article/climate-milestone-earths-co2-level-passes 
spheric levels revealed in the Russian Vostok ice core extracted in Antarctica reveals this concentration of carbon dioxide to be at the highest level in 400,000 years. ${ }^{30}$ About $60 \%$ of the carbon dioxide released from burning fossil fuels stays in the atmosphere, where the sun heats it. The warmer atmosphere not only melts glaciers but is thawing out permafrost soils and organic plant materials embedded in the tundra of the Arctic. Frozen tundra comprises about $24 \%$ of the lands of the Northern Hemisphere. The air across the Arctic, in Siberia, Alaska, and Canada, is warming twice as fast as other regions. As tundra thaws, it releases carbon dioxide and methane into the atmosphere. If the tundra's organic matter, dead plant materials or peat, is kept wet, then the gases can be kept sequestered and their release into the atmosphere can be prevented. However, but if the tundra dries, the oxidation process releases carbon dioxide, and wildfires can exacerbate this process. Thawing tundra can release diseases long ago frozen, and also undermines buildings. ${ }^{31}$ Once dried, the greenhouse gas emissions from the Arctic can cause a sudden rise in global temperatures, leading to acceleration of all climate change impacts.

Vast peat deposits are also found in other regions, such as in the Congo of Africa or Brazil's Amazon Basin. The draining and clearing of wet tropical forests in Indonesia to establish commercial plantations for producing palm oil has exposed peat to oxidation. Fires are used to clear the forest, igniting the peat. Indonesia's severe air pollution from these forest fires impacts people and nature in Kalimantan and Sumatra, and reaches as far as Singapore, Malaysia, and even The Philippines. Indonesia releases a volume of carbon dioxide from the peat so great that it is 'tied' with China and the USA as among the world's greatest emitters of greenhouse gases. The remedy (as it is also for tundra) is to rewet the peat and stop the oxidation, sequestering the carbon dioxide in the wet ground. However, economic pressures for commercial production of palm oil and weak legal regimes currently prevent implementing this relatively easy and comparatively inexpensive remedy.

Thus, even if all fossil fuel burning were to be ended soon, it is probable that existing warming trends have already triggered natural responses that will cause the increase in atmospheric temperature to exceed the levels that sustain our contemporary world's patterns of civilization. We can only dimly perceive

-40o-ppm/\#: :text=On\%2oMay\%209\%2C\%2O2O13\%2C\%2oan,million\%2oyears\%2o of\%2oEarth\%2ohistory>.

30 J-M BARNOLA, et al 'Historical $\mathrm{CO}_{2}$ record from the Vostok ice core'. In Trends: A Compendium of Data on Global Change. Carbon Dioxide Information Analysis Center $<$ https://cdiac.ess-dive.lbl.gov/trends/co2/vostok.html>.

31 Reene CHO, 'Why Thawing Permafrost Matters,' State of the Planet (Columbia University, January11,2018)<https://blogs.ei.columbia.edu/2018/o1/11/thawing-permafrost-matters/>. 
what will be experienced in the near future..$^{32}$ For the month of May, 2019, the Mauna Loa Observatory in Hawaii reported that the carbon dioxide concentration was at a new high, $417.16 \mathrm{ppm} .{ }^{33}$ As the greenhouse gas concentrations rise, so does the warming of the atmosphere. As our human activities augment climate change, they also magnify the environmental degradation that we now endure. This will get worse.

Yet these trends need not become the destiny of humankind. Humans are resilient and have the capacity to adopt principles and policies to guide human society to curb and reverse such deteriorating trends. Globally, the principles agreed at Stockholm in 1972, ${ }^{34}$ and then at the 1992 Rio Earth Summit ${ }^{35}$ and the 2002 Johannesburg World Summit on Sustainable Development (WSSD), ${ }^{36}$ were important steps. However, as humans continue an assault on Earth's environment, it is evident that adopting Agenda 21, the Rio Declaration, the Johannesburg Declaration ${ }^{37}$ have been necessary, but not sufficient steps. While each is progressive, they have not yet integrated environmental protection with social and economic goals (the three pillars of sustainable development). Further steps are needed.

The United Nations General Assembly has continued consultations among UN Member States about the principles that governments will need to define and agree upon to sustain ecological and economic social development. These consultations serve to guide governments as they prepare for the 5 oth anniversary of the 1972 Stockholm Conference, the 3oth anniversary of the 1992 Rio Earth Summit Meeting, and the 2oth anniversary of the UN Johannesburg World Summit on Sustainable Development. 2022 will be a very significant year. It will be more than an anniversary. The Member States of the United Nations cannot avoid taking stock of the existential crises all nations are experiencing on planet Earth. Too many governments ignore scientific assessment

32 See, eg the science fiction novel by Kim Stanley ROBINSON, 'New York 2140' (NY Orbit, 2017), which describes how life goes on in New York City with many places under water due to sea-level rise.

See: <https://www.msn.com/en-ca/weather/topstories/carbon-dioxide-at-mauna-loa -reaches-new-record-high-at-417-ppm/ar-BB15VuKj>. (The Observatory reports its findings each day).

34 Stockholm Declaration (n 3$)$.

35 Rio Declaration (n 7 ); and see ROBINSON (n 6).

36 Report of the World Summit on Sustainable Development, 26 August-4 September 2002, $<$ A/Conf.199/2o/Corr.1 > at <https://sustainabledevelopment.un.org/milesstones/wssd >.

37 United Nations World Summit on Sustainable Development, 26 August-4September 2002, Declaration A/C.2/57/L.83 (UNGA Res. 10 December 2002) <https://www.un.org/ga/ search/view_doc.asp?symbol=A/C.2/57/L.83\&Lang=E $>$. 
of environmental degradation. Earth's biosphere is rapidly changing, and prospects for human wellbeing are diminishing steadily. Present, and increasingly future, generations are at risk. ${ }^{38}$

Can environmental law experts help diplomats and their governments to identify the principles that could guide international cooperation in 2022 and beyond? In 2017, jurists from all regions were involved in preparing a 'global pact for the environment' which France proposed to the United Nations. ${ }^{39}$ The 'pact' would codify those principles. UN Member States demurred, yet agreed that more study was needed to reach consensus on the issues raised by the proposals for the 'pact.' They commissioned the UN Secretary-General's Report on Gaps in International Environmental Law. ${ }^{40}$ The severity of ecological degradation around the world will likely accelerate negotiations to arrive at a new political declaration to guide ecological stewardship. If the 5 oth anniversary of the UN Stockholm Conference passes without a political declaration that is at least as important as the 1992 Rio Declaration, the consensus for the SDGs will likely erode. Conversely, if agreed principles emerge in or shortly after 2022, humankind can unite behind a common vision, despite geo-political differences among nations. The foundations for shared legal principles exist and can be invoked to foster a transition to an ecological civilization.

38 This article, first delivered as a paper at the conference on Ecological Civilization and Global Environmental Governance under the auspices of the Research Institute of Environmental Law of Wuhan University, and the Centre for Ecological Civilization and the Rule of Law, Hainan University in Hainan, China in October 2019 expressed the following concern: 'The participants in this workshop on ecological civilization are all teachers. Our students, our children, are messengers whom we send into a future that we shall never personally know. We owe it to them to equip them with the skills and knowledge, and resilience, that they each shall need.'

39 See Global Pact draft text at <https://www.iucn.org/commissions/world-commission -environmental-law/resources/wcel-important-documentation/global-pact -environment>.

40 See Report of the Secretary-General, 'Gaps in international environmental law and environment-related instruments: towards a global pact for the environment,' A/73.419 (30 November 2018) (hereinafter 'Secretary-General's Report') <https://www.iucn.org/ sites/dev/files/content/documents/global_pact_report.advance.3o_november_2018. pdf $>$. See also the response by the International Council of Environmental Law (ICEL), NOTE (10 December 2020), <https://www.iucn.org/news/world-commission-envi ronmental-law/201812/wcel-announced-today-global-release-wcel-icel-igep-note>, which was presented to the UN General Assembly in a briefing, available in video at <http://webtv.un.org/watch/strengthening-implementation-of-international-environ mental-law/5977795659001/?term=>. 
Humans instinctively love nature, demonstrated for example, by an affinity for landscape painting. In America, public support for the conservation of nature was demonstrated, for instance, by the emergence of the Hudson River School of Painters in the 19th century. ${ }^{41}$ Painters still celebrate the beauty of the Hudson Valley and environmentalists fight to enforce the environmental laws protecting that beauty. ${ }^{42}$ China of course has a much longer-perhaps the world's first - artistic tradition celebrating the beauty of nature. Over the centuries, China has given the world the extraordinary insights into humans and nature that are found in China's genre of landscape painting 山水画 (shān shǔi huà). The pictogram for landscape combines mountain, 山 (shān) and water, 水 (shǔi), thus 山水 (shān shǔi).

Water is integral to life itself. Each human being is composed of about $6 \circ \%$ water, by weight. Water is essential to our daily lives, sanitation and to the well-being of all plants and animals. Water covers most of planet Earth, in our oceans, lakes and rivers and frozen polar regions. Water vapour is an invisible gas in Earth's atmosphere that keeps our atmosphere warm enough for life. It becomes visible in clouds and fogs. In deserts or frozen areas, the amounts of water vapour are miniscule, but in the warm, humid tropics, water makes up $4 \%$ of air. In China's Guilin, everyone in generations past and present marvels at the sight of the waters in the clouds, in the River Li, and among the verdant mountains. This landscape is of world renown. It symbolises how plants, water, rocks and soil, winds and clouds constitute ecological relationships everywhere on our Earth. How marvellous is the water molecule, $\mathrm{H}_{2} \mathrm{O}$ !

But something is wrong with this picture. We know the value of water, yet worldwide we pollute it. We place landscape paintings in museums, while our

41 The beauty of the Hudson inspires the environmental legal education programs of the Elisabeth Haub School of Law at Pace University (at which the author was a member of the faculty that founded the school) and that of many others in different disciplines. See the Hudson at <https://law.pace.edu/academics/juris-doctor-program/ environmental-law-program>.

42 See the discussion of the Hudson in WANG Xi, Albert K BUTZEL, Richard L OTTINGER, Nicholas A ROBINSON, John Louis PARKER, Taryn L RUCINSKI, Marla E WIEDER, Radina R VALOVA, and WANG Pianpian, Assessing Environmental Governance of the Hudson River Valley: Application of an IPPEP Model, 31 Pace Envtl. L. Rev. 1 (2014) $<$ https://digitalcommons.pace.edu/pelr/vol31/issi/1>; Part 1 of this article describes the Interactions of Parties in the Process of Environmental Protection (IP PEP) Model. Part 2 is a brief introduction to the history of Hudson River Valley. Part 3 introduces the major parties or players in the process of protecting the Hudson River Valley. Part 4 consists of five case studies applying the IPPEP Model concerning Hudson River Valley conservation. 
trash accumulates on the land. We cut so many trees that waters erode the mountains. We experience expanding areas of desertification. Our air emissions aggressively warm our atmosphere and yet we are surprised whenever heavier rains flood our human settlements. Even in beautiful Guilin, the habitat of bats was disrupted and the bats (Rhinolophus ssp) then shed their viruses, resulting in the SARS-CoV afflicting humans. ${ }^{43}$ As GEO-6 reports, Earth endures a worsening ecological crisis, and no nation or place is spared. ${ }^{44}$

Can we establish legal norms that give primacy to the human instinct to love, admire, and care for nature? This is the core question for our discipline of environmental law. Efforts to define such norms can be found across all legal traditions: Socialist Law, Civil Law, Common Law, in diverse theocratic legal systems or in the customary law of indigenous peoples. ${ }^{45}$ Diverse illustrations exist in the common and civil law traditions, reaching back in time, for example, to the Forest Charter of $1217 .{ }^{46}$ All contribute to shaping the general principles of international environmental law, as agreed in the 1972 Stockholm and 1992 Rio Declarations.

The pressing need to more effectively address global environmental degradation today motivates States to seek consensus to strengthen the normative foundations for environmental governance. Nations require coherent and consistent systems to sustain Earth's ecosystems. If any region fails to protect the biosphere, it harms all other regions. This logic supports the negotiations launched by UN General Assembly Resolution (in September 2019) ${ }^{47}$ on the pathways forward to address the proposed Global Pact for the Environment. ${ }^{48}$ It explains the importance worldwide of the profound analysis that is reflected in the policies of ecological civilization, (shēngtài wénmíng 生态文明).

43 See David QUAMMEN, Spillover-Animal Infections and the Next Pandemic (2012) 196-202.

44 GEO-6 ( $\mathrm{n}_{15}$ ).

45 Including, for example, the UN Resolution on 'Mother Earth', International Mother Earth Day UNGA A/RES/63/278 (22 April 2009).

46 NA ROBINSON, 'The Charter of the Forest: evolving human rights in nature', in R-L EISMA-OSORIO, E KIRK, and JS ALBIN, The Impact of Environmental Law: Stories of the World We Want (Edward Elgar, 2020).

47 UNGA Res. 73/333. Follow-up to the report of the ad hoc open-ended working group established pursuant to General Assembly resolution 72/277 (30 August 2019).

48 See Maria Antonia TIGRE, Gaps International Environmental Law: Toward a Global Pact for the Environment (January 2020), published for the International Council of Environmental Law (ICEL) <https://www.eli.org/eli-press-books/gaps-international -environmental-law-toward-global-pact-environment $>$. 
To make the transitions to ecological civilization, governments will need to coalesce around a range of environmental principles of law. Such principles will extend far beyond the traditional ones, such as those studied by the United Nations International Law Commission. ${ }^{49}$ There is already a congruence among ecological norms, including those providing the foundations for international environmental law and for the United Nations Sustainable Development Goals (SDGs).

\section{The Role of International Environmental Law and Policy}

\subsection{International Environmental Law}

International environmental law consists of several hundred bilateral and regional treaties on shared natural resources and several multilateral environmental agreements (MEAs), such as the Convention on Biological Diversity. ${ }^{50}$ These 'hard law' agreements reflect a larger body of declarations and policies adopted by the United Nations, the Conferences of the Parties to the MEAs, and other international organizations, such as the Arctic Council or the World Conservation Congress of the International Union for the Conservation of Nature (IUCN). Fundamental to all are the general principles of environmental law, acknowledged by States and by scholars and publicists of international law. State practice emerges as customary international law; for example, the duty to undertake environmental impact assessments. ${ }^{51}$ Custom emerges also from state practice and it may be said that the basic duty to protect the environment, contained in the constitutions of more than half of the world's nations, ${ }^{52}$ and reflected in national environmental legislation and judicial decisions, is emerging as custom. ${ }^{53}$

49 See Marcelo VÀZQUEZ-BERMÚDEZ, Special Rapporteur, 'Second Report on general principles of law' A/CN.4/741 (9 April 2020), available at <https://documents-dds-ny .un.org/doc/UNDOC/GEN/N2o/o93/44/PDF/N20o9344.pdf?OpenElement>.

$5^{\circ}$ A comprehensive list of treaties is available at ECOLEX <https://www.ecolex.org/ result $/$ ?type $=$ treaty $>$.

51 See Judgment of 20 April 2010, by the International Court of Justice in Pulp Mills on the River Uruguay (Argentina v. Uruguay) <https://www.icj-cij.org/en/case/135/judgments >.

52 Erin DALY and James R MAY, Implementing Environmental Constitutionalism, Cambridge UP 2018, 2.

53 See generally Lal KURUKULASURIYA and Nicholas A ROBINSON (eds), UNEP Training Manual on International Environmental Law (UNEP 2006). 
The 1987 Montreal Protocol on Substances that Deplete the Ozone Layer is an example of a very effective and universally implemented instrument of international environmental law. ${ }^{54}$

The Protocol controls releases of ozone-depleting substances, and is based on basic principles (highlighted in italics) set forth in its preamble: 'Considering the importance of promoting international co-operation in the research and development of science and technology relating to the control and reduction of emissions of substances that deplete the ozone layer, bearing in mind in particular the needs of developing countries. ${ }^{55}$ Underlying this Protocol is the Vienna Convention for the Protection of the Stratospheric Ozone Layer of $1985 .{ }^{56}$ The Vienna Convention cites several principles of law in its preamble, including Principle 21 of the Stockholm Declaration and the precautionary principle. While similar principles are found on other MEAs, few so closely tie government duties to stewardship of the natural system being protected.

Although all nations have acted to protect the stratospheric ozone layer, it is unclear whether and when the ozone 'hole' will be closed. It took decades for the ozone-depleting substances to erode the ozone layer, and it may take even longer for the ozone layer to be fully recovered once the harmful substances are removed. This illustrates one of the problems of care for the environment. Prevention is far better than repairing the damage, for the latter may not be possible and will always take time and resources (illustrating Benjamin FRANKLIN's maxim that 'an ounce of prevention is worth a pound of cure'). The precautionary principle provides a particularly apt example of this.

Thus, while nations have adopted a large body of international environmental law, not all of it is yet fully effective. Few agreements have universal membership of States. Most nations imperfectly implement their treaty obligations. Governments' gradualist approach to adopting and implementing MEAs leave much of the global environment unprotected. This allows environmental harm to accumulate more rapidly than it is prevented. For this reason, there is urgency in the study of how norms of ecological civilization might provide a strong foundation for more effective implementation of both national and international environmental law. A new paradigm for ecological stewardship is needed as soon as possible.

54 See <https://treaties.un.org/doc/Publication/UNTS/Volume\%201522/volume-1522-I -26369 -English.pdf $>$.

55 See <https://treaties.un.org/doc/Publication/UNTS/Volume\%201522/volume-1522-I -26369 -English.pdf>.

$56 \quad 1513$ UNTS 293. 
The duty of States to cooperate to safeguard Earth's environment can be enhanced through having a shared understanding of the norms contained in the concept of ecological civilization. This can improve environmental governance by making clear the imperative to observe fully the laws for environmental stewardship. Ecological, economic and social benefits would then flow from robust use of common legal tools, such as environmental impact assessment (EIA), ${ }^{57}$ or sustaining ecological systems in protected areas, such as under the UnESCO World Heritage ${ }^{58}$ and Biosphere Reserve programs. ${ }^{59}$

\subsection{Ecological Law and Ecological Civilization}

It is instructive to briefly compare the development of the concept of ecological civilization and its ramifications for environmental law in China in the 20oos with the development of what was then termed 'ecological law' in the Soviet Union in the 1980s. The concept of 'ecological culture' (экологической культуры) developed by Russian jurists has clear similarities to the concept of ecological civilization. The late Prof Oleg Stepanovich KOLBASOV ${ }^{60}$ outlined how socialist legal doctrine should reflect the basics of ecological science. ${ }^{61}$ KOLBASOV was critical of the shallow implementation of the Soviet laws for protection of nature: 'Inadequacies which diminish the effectiveness of the laws ... should be eliminated. We are speaking here of the excessive complexity, declarativeness, contradictoriness and drafting inefficiencies of the environmental protection legislation. ${ }^{62}$ Although for a time under perestroik $a^{63}$ efforts to improve ecological law progressively improved, ${ }^{64}$ environmental law later regressed when socialist legal frameworks were replaced by undisciplined

57 See the EIA capacity-building publications of the UN Environment Programme $<\mathrm{https}: / /$ unep.ch/etb/publications/envilmpAsse.php>.

$5^{8}$ UNEsco World Heritage Centre <https://whc.unesco.org/>.

59 UNESCO Biosphere Reserves, at $<$ https://en.unesco.org/biosphere $>$.

6o KOLBASOV is remembered as the Father of Environmental Law in Russia, and served on the Russian Delegation to the 1992 UN Conference on Environment and Development (UNCED) in Rio de Janeiro where the concept of sustainable development was endorsed as an international policy.

61 OS KOLBASOV, Ecology: Political Institutions and Legislation (Progress Publishers, Moscow 1976). See also KOLBASOV's work in Irina O KRASNOVA (ed) OS KolbasovThe Best Works (2017).

62 OS KOLBASOV, 'Compliance with Nature Protection Legislation' Sov. Gos. Pravo, No 4, Russian Academy of Sciences, Institute of State and Law (1988).

63 'Restructuring' in Russian: it was a movement for political and economic reformation in the Soviet Union in the late 1980 os.

64 See Nicholas A ROBINSON, 'Perestroika \& Priroda: Environmental Protection in the USSR,' 5 Pace Envir'l L. Rev. 351 (1988); see also Tatiana ZAHARCHENKO, 'The Environmental Movement and Ecological Law in the Soviet Union:The Process of Transformation,' 
capitalist market forces exploiting natural resources, and by an erosion of socialist legality in administration of all laws.

KOLBASOV understood ecological relationships, and the need for jurists to become partners with ecologists in helping shape social norms that maintained the health of people in their natural settings. The successful, vast Russian systems of strictly protected areas (zapovedniki or заповедники), ${ }^{65}$ are ехаmples of what ecological law supports. In like vein, KOLBASOV encouraged the Central Committee of the Communist Party and Council of Ministers of the Soviet Union to support the progressive development of international environmental law. He supported a stronger regime for 'ecological expertise,' which was originally a Soviet version of EIA, conceived independently of the systems that emerged later in the USA and internationally. He advanced ways to improve the effectiveness of EIA, in the USSR, in the Russian Federation, and regionally in Europe as in the Espoo Convention and Aarhus Convention. He understood that EIA was essential to ensuring the effectiveness of ecological law. He later was Vice Minister of the Russian Federation's Environment Ministry, and with a sure understanding of ecological law, for a time he was able to align Russian international legal policies with the progressive development of international environmental law. He was for many years a regional Vice Chair of the Commission on Environmental Law of the International Union for the Conservation of Nature (IUCN) and during 1972-1992 chaired the Soviet side of the environmental law cooperation negotiations with his American counterparts under the 1992 USA-USSR Agreement on Cooperation in the Field of Environmental Protection. ${ }^{66} \mathrm{He}$ well understood the principle of cooperation, as did all those on both the USA and USSR sides in that period. ${ }^{67}$

Russia has continued to support the concepts of sustainable development, ${ }^{68}$ but without the firm foundation of ecological law to make sustainability a

17 Ecology Law Quarterly 454 (1990) <https://scholarship.law.berkeley.edu/cgi/viewcon tent.cgi? article $=1380 \&$ context $=$ elq $>$.

65 Tatiana R ZAHARCHENKO, 'Environmental Policy in the Soviet Union,' 14 Environs 3 (Environmental Law and Policy Journal, University of California at Davis, 1990) <https:// environs.law.ucdavis.edu/volumes/14/1/articles/zaharchenko.pdf>.

66 U.S. State Department, Treaties and Other International Acts Series 7345-May 23, 1972 $<$ https://archive.epa.gov/epa/aboutepa/us-and-ussr-sign-environmental-cooperation -treaty.html>.

67 See the memoirs of Russell E TRAIN, Politics, Pollution and Pandas (Island Press, Washington DC 2003).

68 Report on implementing the Principles of Sustainable Development in the Russian Federation: Russian Outlook on the New Paradigm For Sustainable DevelopmentPreparing For 'Rio+2o' (Moscow 2012) <https://sustainabledevelopment.un.org/content/ documents/1043natrepeng.pdf>. 
management priority, it very often remains too 'declarative' and not operational. The strengths and weaknesses of ecological law in the UssR and Russia can be usefully examined by those furthering ecological civilization in China and internationally.

\subsection{The UN Sustainable Development Goals}

Much about 'sustainability' has also proven to be declarative and aspirational. Since the early 1980s when IUCN first advanced the concept in Caring for the Earth, ${ }^{69}$ and after the UN World Commission on Environment and Development presented the concept, and proposed legal principles to advance their implementation, in Our Common Future, ${ }^{70}$ nations have struggled to elaborate and give substantive content to the concept of sustainability.

Many questions abound: What does it mean in practice to only use resources that are needed today to ensure that future generations will have the resources that they need also? What is equitable? Even while sustainability is not fully understood, since the 1992 Earth Summit in Rio de Janeiro, sustainable development has become established international policy. In 2015, the United Nations General Assembly agreed, by consensus after three years of negotiations, that the agreed pathway forward for socio-economic development through 2030 would be the United Nations Sustainable Development Goals (SDGs). ${ }^{71}$ This '2030 Agenda for Sustainable Development' identifies 17 Sustainable Development Goals and 169 targets that have been agreed in order to coordinate and guide all efforts at socio-economic and environmentally sound development in all nations. Unfortunately, since 2015, the environmental conditions across the Earth have deteriorated further. Adoption of the SDGs does not equate with implementing the effective measures necessary to attain them. There are many available means to attain the sDGs. ${ }^{72}$ What is lacking is the political will to do so. If the SDGs are to be embraced as a priority, it is evident that some strategic, fundamental norms will be needed to motivate and

69 Caring for the Earth (IUCN, UNEP < FAO, 1991) < https://portals.iucn.org/library/node/ $6439>$.

70 Report of the UN World Commission on Environment \& Development, Our Common Future (1987), <https://sustainabledevelopment.un.org/content/documents/5987our -common-future.pdf>, and its 'Annex 1: Summary of Proposed Legal Principles for Environmental Protection and Sustainable Development Adopted by the WCED Experts Group on Environmental Law.

71 'Transforming Our World: The 2030 Agenda for Sustainable Development' (n 8).

72 See Nikhil SETH, Castor M Diaz BARRADO, and Paloma Duran y LALAGBNA, SDGs: Main Contributions and Challenges (UNITAR, 2019). 
establish this prioritization. Implementation of the SDGs has been too slow to ensure that they can be attained in 2030.

In his Sustainable Development Goals Report 2019, ${ }^{73}$ UN SecretaryGeneral António GUTERRES sets forth how States have sought to integrate the SDGs and targets into their national development plans. Notwithstanding these efforts, in introducing the Report he explains: 'It is abundantly clear that a much deeper, faster and more ambitious response is needed to unleash the social and economic transformation needed to achieve our 2030 goals. ${ }^{74}$ The Report indicates that human well-being is undermined by the environmental problems.

Attaining the environmental SDGs, those for water (Goal 6), for reliable energy (Goal 7), for climate (Goal 13), for oceans (Goal 14) and for the terrestrial ecosystems (Goal 15), face gigantic obstacles. Yet if States fail to attain these, then all the other SDGs will also be more difficult to achieve. In 2018, the Sustainable Development Solutions Network published a report providing data to show that no country in the world is on track to achieve all the goals by $2030 .{ }^{75}$ Dr Jean-Paul MOATTI, a member of the UN expert group charged with evaluating progress of the goals, indicates that most SDGs are actually trending in reverse. ${ }^{76}$ The Sustainable Development report 2020, prepared with the COVID 19 pandemic front and centre, makes this picture even worse. ${ }^{77}$ Given the deteriorating environmental trends documented in GEO- $6^{78}$ and the effect of COVID 19, all the SDGs may well fall short of attainment in 2030 .

The SDGs aim to sustain the environmental integrity needed for the health of our global home and civilization. If 'ecological law' became a unified field of jurisprudence, it could serve to support the SDGs. Ecological law offers a juridical foundation for the laws and policies that aim to maintain a healthy environment for people and nature and embodies the duty to respect and

73 UN Department of Economic and Social Affairs, 'Sustainable Development Goals Report 2019' <https://www.un.org/development/desa/publications/sustainable-developmentgoals-report-2019.html>

74 Sustainable Development Goals Report 2019 (n 2 ) 2.

75 J SACHS et al (2018) SDG Index and Dashboards Report 2018. New York: Bertelsmann Stiftung and Sustainable Development Solutions Network, viii.

76 Jean-Paul MOATTI, Director-General of the French National Research Institute for Development, interview on SciDev, Ben DEIGHTON, 'Q\&A: Most SDGS going in reverse-UN expert group member,' (2 April 2019), available at <https://www.scidev.net/global/sdgs/ opinion/most-sdgs-going-into-reverse-un-expert-group-member-1x.html>.

77 J SACHS et al (2020): The Sustainable Development Goals and Covid-19. Sustainable Development Report 2020 (Cambridge: Cambridge University Press).

78 GEO-6 (n 15). 
restore the integrity of Earth's natural systems that sustain life. ${ }^{79}$ This scope is more holistic than that of SDGS 14 and 15, concerning the planet's marine and terrestrial environment. Ecological law implies a pervasive duty, shared by all individuals, social organizations, political parties, and governments at all levels. However, the SDGs do not yet explicitly state a core duty to give primacy to environmental stewardship, which is a weakness. It falls, therefore, for all who specialize in environmental law to examine whether general principles of ecological law might make possible, or more likely, the attainment of the SDGS, and if so, how.

Environmental law received an important recognition on November 30, 2018, when the United Nations Secretary-General issued his report, 'Gaps in international environmental law and environment-related instruments: towards a global pact for the environment.' 80 The report addressed general principles of international environmental law. It is useful to expand upon this report, ${ }^{81}$ and elaborate on its analysis. As proponents of ecological law explain, ${ }^{82}$ one cannot fill the gaps in international environmental law because the premise of the law itself is flawed, it is still based on the laws of humans manipulating nature. Since human life depends on the health of Earth's biosphere, human laws must be grounded in the laws of nature and ecology. Until our laws reflect this approach, there will inevitably be gaps and shortcomings. When it is acknowledged that international environmental law is incomplete, it is in effect a signal that studies should seek an understanding of how norms such as those

79 The scope of ecological law is broader than that of environmental law, and reflects the four laws of ecology that Barry COMMONER advanced in his work The Closing Circle (1971). See also the work of the Ethics Specialist Group of the IUCN World Commission on Environmental Law that adopted the Oslo Manifesto for Ecological Law and Governance (June 2016) <https://elgaworld.org/oslo-manifesto >. As a distinct new and emerging field of law, it requires a shift from environmental law to ecological law; see Klaus BOSSELMANN, Foreword, in K ANKER, PD BURDON, G GARVER, M MALONE, and C SBERT (eds) From Environmental to Ecological Law (Routledge, 2020).

8o UN Report A/73/419.

81 See the commentaries offered by the International Council of Environmental Law, assembled by the IUCN World Commission on Environment Law <https://www .iucn.org/commissions/world-commission-environmental-law/wcel-resources/ global-pact-environment>.

82 ANKER et al ( $\mathrm{n}$ 79). 
arising from 'ecological civilization' can contribute principles of law that build a reciprocity between the human species and all other species and ecosystems.

Principles of environmental law were first set forth at the 1972 UN Stockholm Conference on the Human Environment, which adopted the Stockholm Declaration. ${ }^{83}$ The Stockholm Conference recognized the environmental right and duty in the Stockholm Declaration's first principle in $1972 .{ }^{84}$ This expression was based on the assumption that the Earth's environment was stable and capable of being sustained. Principle 2 provided that: "The natural resources of the earth, including the air, water, land, flora and fauna and especially representative samples of natural ecosystems, must be safeguarded for the benefit of present and future generations through careful planning or management, as appropriate.' These principles set the stage for subsequent deliberations about how to more clearly recognize and observe the right to the environment. Their concepts also inform the quest to define the norms of ecological civilization.

The search for ecological principles has been clouded by its primary focus on international law, rather than on the science of ecology. Human laws need to conform to the laws of nature, not the other way around. For example, Ambassador LANG observed 20 years ago that while some scholars link the adoption of principles to the progressive development of international law, 'professional lawyers ... agree that such principles cannot stand alone but need transformation into binding obligations in order to play their role in international life. ${ }^{85} \mathrm{He}$ did acknowledge that Prof Paul SZASZ had justification

83 Stockholm Declaration ( $\left.\mathrm{n}_{3}\right)$; the Declaration's preamble states that 'Man is both creature and moulder of his environment, which gives him physical sustenance and affords him the opportunity for intellectual, moral, social and spiritual growth. In the long and tortuous evolution of the human race on this planet a stage has been reached when, through the rapid acceleration of science and technology, man has acquired the power to transform his environment in countless ways and on an unprecedented scale. Both aspects of man's environment, the natural and the man-made, are essential to his well-being and to the enjoyment of basic human rights the right to life itself.' Preamble paragraph 1, Stockholm Declaration on the Human Environment, at <www.un-documents.net/unchedec.htm>; see also Ben BOER, 'Environmental principles and the right to a quality environment,' in Ludwig KRÄMER and Emanuela ORLANDO (eds), Principles of Environmental Law, Elgar Encyclopedia of Environmental Law, Vol vI, (2018) 52, 57 (hereinafter KRÄMER and ORLANDO).

84 Stockholm Declaration Principle 1 states 'Man has the fundamental right to freedom, equality and adequate conditions of life, in an environment of a quality that permits a life of dignity and well-being, and he bears a solemn responsibility to protect and improve the environment for present and future generations.'

85 Winfried LANG, 'UN-Principles and International Environmental law', Max Planck Yearbook of United Nations Law, UNYB 3 (1999) 157 <http://www.mpil.de/en/pub/publica tions/periodic-publications/max-planck-yearbook/volume-3.cfm>. 
when he 'stressed the important role of legislative declarations as they may be precursors to and guide a later treaty-making process and are designed to influence the conduct of states directly. ${ }^{\prime 6}$ LANG further observed that 'French scholars distinguished by the mid-eighties between 'principes directeurs' and 'principes inspirateurs.' Among the former were principles for environmental impact assessment, information and consultation, early warning in case of accidents, non-discrimination and equal treatment. In the second group were principles for sovereignty in exploiting one's natural resources, solidarity and cooperation, equitable utilization of common resources, and safeguarding of the common heritage of humankind. ${ }^{87}$

These debates about the principles concerning environmental law have preoccupied jurists but have done little to protect nature. Until the tepid acceptance of the Paris Agreement in $2015,{ }^{88}$ it was thought that the consensus about existing principles of international environmental law had progressively become more widely accepted. ${ }^{89}$ Many principles indeed are now 'accepted' (eg EIA and public participation in environmental decision-making) but are not necessarily widely observed or enforced. Others remain as 'emerging' principles (eg intergenerational equity, and duties to future generations). Moreover, as Emanuela ORLANDO and Ludwig KRÄMER observe, in addition to widely recognized environmental principles across different legal jurisdictions and at international level, 'other environmental principles have emerged in particular legal systems, reflecting the needs, aspirations and objectives of that particular culture and legal traditions. ${ }^{90}$ They cite the example of the 'protection first' principle in China and the 'public trust doctrine', inherited from the US, which they note is being applied with increasing regularity by courts in environmental cases in India and Sri Lanka. ${ }^{91}$

Despite the progressive acceptance of environmental legal principles, environmental degradation has also progressed. Environmental harm cannot be averted until States embrace a clearer legal mandate that ends harmful conduct. Similarly, the SDGs are not likely to be attained without a firmer legal

86 ibid 158.

87 ibid 161. See also Maurice KAMPTO, 'Les Nouveaux principes du droit de l'environnement,' Revue juridique de l'environnement 18:1 (1993) 11-21.

88 Paris Agreement, under the UN Framework Convention on Climate Change, at $<$ https://unfccc.int/files/essential_background/convention/application/pdf/english_ paris_agreement.pdf $>$.

89 Philippe SANDS and Jaqueline PEEL, Principles of International Environmental Law (Cambridge, 4th ed. 2018); see in particular 'General Rules and Principles', 197-251.

9o Ludwig KRÄMER and Emanuela ORLANDO, 'Introduction,' in KRÄMER and Emanuela ORLANDO (n 83) 2.

$91 \quad$ ibid 2. 
foundation. UN Member States were unwilling in 2018 to accept the proposed Global Pact for the Environment. ${ }^{92}$ They still need to find a consensus on the most basic of foundational norms. They eventually will need to build a jurisprudence of ecological law, and its transition from environmental law. Ongoing capacity-building, like that of the Montevideo Environmental Law Programme, ${ }^{93}$ is helpful to provide for the transition to ecological law, but without the guiding star of a strong ecological law principle, Earth's natural systems and human societies will continue their decline.

The practical steps toward attaining the SDGs and 'the future we want' 94 may emerge from the UN negotiations to the year 2022. The international community of nations will need to marry its consensus on the SDGs with a clear acknowledgment of the right to the environment and the correlative duty to care for the environment. Jurists proposed such provisions for a Global Pact in $2017:^{95}$

Every person has the right to live in an ecologically sound environment adequate for their health, well-being, dignity, culture and fulfilment.

Every State or international institution, every person, natural or legal, public or private, has the duty to take care of the environment. To this end, everyone contributes at their own levels to the conservation, protection and restoration of the integrity of the Earth's ecosystem.

While these norms generally reflect the 1972 Stockholm Declaration, States have not consistently observed or supported these principles. The 5oth anniversary of the Stockholm Declaration in 2022 can be the time for States to agree on these provisions as clear, peremptory norms, as ius cogens, ${ }^{96}$ (norms from which no derogation may be permitted). Ecological civilization depends on

92 'Towards a Global Pact for the Environment,' UNGA Resolution 72/277 (10 May 2018), reaffirmed and extended in UNGA Resolution 73/333 (5 September 2019).

93 Unep, Montevideo Programme for the Development and Periodic Review of Environmental Law, Montevideo v: A Decade of Environmental Law <https://www.unenviron ment.org/explore-topics/environmental-rights-and-governance/what-we-do/ promoting-environmental-rule-law-1>.

94 Since 2012, nations have agreed on 'The Future We Want' as the umbrella for their cooperation in favor of sustainable development. See $<$ https://sustainabledevelopment.un.org/ index.php? page $=$ view\&type $=400 \& n r=733 \&$ menu $=35>$.

95 See the Preliminary Draft of the Group of Experts for the 'Global Pact for the Environment' Articles 1 and 2 (hereinafter 'Global Pact') <https://globalpactenvironment.org/uploads/ EN.pdf>.

96 See Article 53, Vienna Convention on the Law of Treaties. See also K GASTORN, 'Defining the Imprecise Contours of Jus Cogens in International Law,' Chinese Journal 
adhering to this Grundnorm ${ }^{97}$ (a basic or foundational norm). Agreeing on this Grundnorm can be the principal outcome of the consultations pursuant to UNGA Resolution $72 / 277^{98}$ and Resolution $73 / 333 .{ }^{99}$

During the months before 2022, there is the opportunity for States to debate and agree upon a set of general principles of international cooperation to sustain Earth's biosphere. Even if they do not reach agreement on a transition to ecological law, there are currently a variety of different expressions of accepted international environmental legal principles that could be restated and codified, including the right to the environment. A new political declaration would provide the ius cogens to arrest further degradation of life on Earth.

There also would be many practical benefits from a new political declaration. In cases where more than one expression of a particular principle is found, it would be useful to have a single agreed text to 'provide for better harmonization, predictability and certainty' in international environmental law. ${ }^{100}$ As the disruptions caused by climate change increase and the sixth great extinction of species ushers in biodiversity crises, pressure on governments will grow to cooperate more effectively. New principles will need to be added to the existing ones. It will become important to elevate emerging principles, such as the principle of resilience. ${ }^{101}$ States will need to agree upon the progressive development of the law necessary to deal with Earth's changing, new, and real conditions. Jurists such as Shailendra Kumar GUPTA ${ }^{102}$ and Marie-Claire CORDONIER SEGGER largely agree on the same range of

of International Law, Volume 16, Issue 4, December 2017, 643-662, (16 January 2018), $<$ https://doi.org/10.1093/chinesejil/jmxo37>.

98 UNGA Res. 72/277 of 1o May 2018 entitled 'Towards a Global Pact for the Environment'.

99 UNGA Res. 73/333 of 30 August 2019 entitled 'Follow-up to the report of the ad hoc openended working group established pursuant to General Assembly Resolution 72/277' (distributed on 5 September 2019).

100 UN Secretary-General's Report (n 40) 43, para 102.

101 For commentaries on all the principles in the Global Pact, see Yann AGUILA and Jorge E VIÑUALES (eds), A Global Pact for the Environment: Legal Foundations (Cambridge, 2019) at <https://globalpactenvironment.org/uploads/Aguila-VinualesA-Global-Pact-for-the-Environment-Cambridge-Report-March-2019.pdf>, and for resilience see Chapter 17: 'The Principle of Resilience,' by Nicholas ROBINSON.

102 Shailendra Kumar GUPTA, 'Principles of International Environmental law and Judicial Response in India,' at p. 3 (Benares Hindu University, Varanasi, India): (1) Principle 21 of the Stockholm Declaration and Principle 2 of the Rio Declaration, namely that states have sovereignty over their natural resources and the responsibility not to cause environmental damage; (2) The principle of preventive action; (3) The principle of good neighbourliness and international co-operation; (4) The principle of sustainable development; (5) The 
principles. ${ }^{103} \mathrm{~A}$ consensus on these principles is reflected in the commentaries for the UNEP Training Manual on International Environmental Law, which describes comparable principles. ${ }^{104}$

The Secretary-General's Report of 2018 itself sets forth nine principles (paragraphs 11-22) worthy of codification and reaffirmation. In addition to these principles, the Report adds the right to a clean and healthy environment, and the principles of non-regression and progression, but does not address the principles of inter-generational or intra-generational equity. The 1972 Stockholm Declaration embraces the right to the environment as a fundamental principle, as well as the principles associated with the duties of States to care for the environment and to enact effective laws to safeguard the environment. Principle 17 of the Rio Declaration obliges States to undertake environmental impact assessment (EIA) in national decision-making that impacts upon the environment, and this norm has become accepted as customary international law. ${ }^{105}$ The draft Global Pact ${ }^{106}$ and the Secretary-General's Report ${ }^{107}$ include EIA as related to the principle of prevention. The Expert Group that prepared the draft Global Pact for the Environment included the principle of caring for the Earth in Article 2 and set forth the emerging principle of resilience in Article 16, which are both implicit in other principles (eg prevention and precaution). There is value in expressing them in a set of agreed principles. ${ }^{108}$

precautionary principle; (6) The polluter-pays principle; and (7) The principle of common but differentiated responsibility.

103 See Marie-Claire CORDONIER SEGGER 'Commitment to sustainable development through international law and policy', in Marie-Claire CORDONIER SEGGER and CG WEERAMANTRY (eds), Sustainable Development Principles in the Decision of International Courts and Tribunals 1992-2012 (Routledge, 2017) 29-98: (1) Sustainable Development; (2) Inter-Generational and Intra-Generational Equity; (3) Responsibility and Transboundary Harm; (4) Transparency, public participation and access to information and remedies; (5) Cooperation and Common But Differentiated Responsibilities; (6) Precaution; (7) Prevention; (8) Polluter pays; (9) Common Heritage and Common Concern of Mankind; (11) Good Governance. See also, Nico SCHRIJVER, 'Advancement in the principles of international law on sustainable development' ibid 99-108.

104 Daniel B MAGRAW and Barbara RUIS, 'Principles and concepts of international environmental law' (in KURUKULASURIYA and ROBINSON) (n 2) 23-38.

105 Pulp Mills on the River Uruguay (Argentina v. Uruguay), Judgment, ICJ Reports 2010, <www .icj-cij.org/en/case/135>; Responsibilities and Obligations of States Sponsoring Persons and Entities with Respect to Activities in the Area, Advisory Opinion, Case No. 17, International Tribunal for the Law of the Sea Reports 2011.

106 Global Pact (n 95) art 5.

107 Secretary-General's Report (n 40) para 11.

108 See also Cymie R PAYNE, 'A Global Pact for the Environment,' 22:12 Am Soc Intl L Insights (2018) <https://www.asil.org/insights/volume/22/issue/12/global-pact-environment>. 
The IUCN World Declaration on the Environmental Rule of Law ${ }^{109}$ includes thirteen principles, many of which are co-extensive with those outlined above. There are also commentaries about how to observe and apply principles to promote sustainable development, for example in China, through environmental management practices ${ }^{110}$ and through external communication of ecological civilization in China. ${ }^{111}$

The principles of ecological civilization can help shape a consensus about restating environmental legal principles generally. States will need to acknowledge their responsibility to operate within the ecological limits of Earth's Biosphere. China can contribute greatly to the global debate about Earth's ecological principles of law by sharing its knowledge and understanding of ecological civilization. This provides a welcome leadership role for China. Because environmental degradation is becoming worse, world-wide, more is required of governments than just again endorsing steps to advance sustainable development. Arriving at an agreement in 2022 on the form and scope of the environmental right and duty would set in train the process for codification of the other environmental law principles that are derived from those fundamental principles.

This need for progressive development of agreed environmental principles is illustrated by the most-cited provision of the 1972 Stockholm Declaration, Principle 21, which governs State obligations and rights inter se. Principle 21 provides that: 'States have, in accordance with the Charter of the United Nations and the principles of international law, the sovereign right to exploit their own resources pursuant to their own environmental policies, and the responsibility to ensure that activities within their jurisdiction or control do not cause

109 World Commission on Environmental Law, IUCN World Declaration on the Environmental Rule of Law 2016 <https://www.iucn.org/commissions/world-commission -environmental-law/wcel-resources/wcel-important-documentation/environ mental-rule-law>.

110 See Xiangbai HE, 'Setting the Legal Enabling Environment for Adaptation Mainstreaming into Environmental Management in China: Applying Key Environmental Law Principles' 17 Asia Pac J Envtl L 23 (2014). See also Yuhong ZHAO, 'Environmental Principles in China', in KRÄMER and ORLANDO (n 83) 424-436; Olga DUBOVIK and Alla RÖHRICT, 'Principles of Russian Environmental Law', in KRÄMER and ORLANDO (n 83) 437448; Samudu ATAPATTU, 'Environmental Law principles in Asia', in KRÄMER and ORLANDO (n 83) 433-475; Hennie STRYDOM, 'Environmental principles in Africa', in KRÄMER and ORLANDO (n 83) 494-506.

11 WANG Quanquan and ZHANG Wei, 'The External Communication of Ecological Civilization in China: Significance, Challenges and Strategies', vol 38, no 5, Journal of South-Central University for Nationalities (Humanities and Social Science), September 2018. 
damage to the environment of other States or of areas beyond the limits of national jurisdiction. Principle 21 poses a problem: how can States know when their conduct may harm a neighbour or the commons? It would seem that observing the principles of prevention and precaution preclude such transboundary harm, and implementing Rio Principle 17 on environmental impact assessment would enable States to observe their duty not to harm neighbours or the commons, or themselves. In order to guide State practice and to build capacity for States to observe Principle 21, States will need to understand their reciprocal and shared duties, to other States, stakeholders, and the entire community of ecological life. These principles for human conduct are inter-related and linked, not unlike ecological systems in nature. For these reasons, States should formally acknowledge that they must share a common set of principles that would further this objective.

Just as the scientific description of the 'laws of nature' throughout Earth's biosphere are open for all to understand, so too is appreciating the instinctive human capacity to love and care for nature. These are complementary, and their relationship needs to be cultivated. Agreeing on legal principles is possible. The planet's environmental degradation lends urgency to the coming dialogue among nations to express a common set of norms for ecological civilization on the planet. Coping with sea-level rise, intense weather events, wildfires, floods and the other consequences of climate change will require resilience.

\section{The Principle of Resilience: an Essential Elaboration of} Environmental Principles of Law

As weak systems of environmental governance break down further in the wake of environmental degradation, principles that further attain the sustainable development goals will now need to be refined and augmented. Some emerging new principles, which have been taken for granted, will need to be cultivated, and none more so than the principle of resilience.

Resilience is a characteristic of life, both human and ecological. Resilience is the behaviour of rebounding or springing back after experiencing a disruption. ${ }^{112}$ It is a property of matter, as discovered in materials science ${ }^{113}$

112 The concept is derived from the Latin word resilio, resiliere - to leap or spring back.

113 For example, Thomas TREDGOLD observed in Practical Essay on the Strength of Cast Iron (London, 1824) <https://babel.hathitrust.org/cgi/pt?id=hvd.hw26r5;view=1up;seq=7> TREDGOLD computes the capacities of cast iron to sustain the weight of pressures: 'the 
but is most remarkable in nature when living beings ${ }^{114}$ or ecological systems ${ }^{115}$ respond to change by recovering and restoring previous capabilities and adapting or evolving anew to a sustainable status. Resiliency has long been admired, as in the case of human capacity to recover from earthquakes and other disasters. Resilience is the capacity to keep going, even after setbacks. The UN Sustainable Development Goals expressly recognizes resilience in two SDGs, Goal 9 on the need for resilient infrastructure, and in Goal 11 on the need for resilient cities and human settlements. On careful analysis, one will see resilience is a dimension in each of the other SDGs also.

Humans have remarked about resilience as a feature of nature, and human nature, for many centuries. CONFUCIUS advised that, 'It does not matter how slowly you go so long as you do not stop.' OVID and other classical poets also described resilience. In the Renaissance, Francis BACON, in his posthumously published writing, Sylva Sylvarum, or A Natural History In Ten Centuries (1672), recognized resilience. The Romantic poet Samuel Taylor COLERIDGE, in his Hymn to Earth (1834), extolls the Earth as divine and celebrates its capacity to renew and give birth anew: 'mightier far was the joy of thy sudden resilience.' Enhancing the human capacity for resilience will keep civilization going.

The Stockholm Resilience Center has amassed a deep and richly varied database of studies and research about resilience. ${ }^{116}$ Surprisingly, perhaps, the Stockholm Center provides relatively few inquiries into law and resilience, except for a conference on 'law for socio-ecological resilience.'117 Some legal

term modulus of resilience I have ventured to apply to the number which represents the power of the material to resist an impulsive force'.

114 The American Psychological Association defines resilience as the process of adapting well in the face of adversity, trauma, tragedy, threats or significant sources of stress-such as family and relationship problems, serious health problems or workplace and financial stressors. It means 'bouncing back' from difficult experiences.' See $<$ https://www .google.com/search?client=safari\&rls=en\&q=health+resilience+definition\&ie=UTF-8 \& $\mathrm{ee}=\mathrm{UTF}-8>$. The public health sector identifies ways to cultivate resilience in society. See Katharine WULFF, Darrin DONATO and Nicole LURIE, 'What is Health Resilience and How can We Build It?' 36 Annual Review of Public Health 361-374 (2015), accessible at <https://www.annualreviews.org/doi/full/10.1146/annurev-publhealth-o31914-122829>.

115 See ecological studies of resilience, such as CS HOLLINGS, 'Resilience and Stability of Ecological Systems' 4 Annual Review of Ecological Systems 1-23 (1973), accessible at $<$ https://www.annualreviews.org/doi/abs/10.1146/annurev.es.04.110173.000245>.

116 Stockholm Resilience Center <https://www.stockholmresilience.org $>$.

117 ibid See 'What is Socio-Ecological Resilience?' <https://www.stockholmresilience.org/ research/research-news/2015-02-19-what-is-resilience.html>; see also Ahjond S GARMESTANI and Craig R ALLEN (eds), Social-Ecological Resilience and Law (Columbia University Press, 2014). 
scholars recognize resilience as a property of legal systems, but not yet as a guiding principle applied through legal systems. Thus, for example, Prof JB RUHL proposes a theory of resilience, but stops short of recognizing it as a principle of law. ${ }^{118}$ He posits the 'resilience approach,' which he suggests 'relies on the adaptive management decision process described above and a broad array of policy instruments from markets to regulations to common law, dynamic multiscalar federalism, and networked agencies and other actors for its underlying structure.'119 RUHL recognizes that encouraging legal systems that support resilience and adaptive management is difficult in the face of the business as usual' approach. He concludes: 'When climate change brings a new regime of high variability and low predictability in natural and social systems, the law must be ready.' His approach is to do so 'in the same way resilience theorists probe other natural and social systems, and it suggests that mapping resilience theory onto the legal system is a fruitful exercise both in general and in particular applications such as to prepare law for climate change.'120 The urgency in responding to global environmental degradation means that society worldwide needs to embrace the duty to enhance resilience as a legal norm now, not after prolonged study.

As a general principle of law, resilience plays a crucial normative role. It is not an elective social policy or merely a desirable element of adaptive management. In human communities, the benefits of a legal principle of resilience can be enhanced and realized, or they can be eroded and denied. This is analogous to a society enjoying a stable system of justice, or suffering when the legal elements needed for a just society are lacking. The responsibility to care for the environment requires measures to enhance resilience in socio-ecologic systems.

To understand resilience as a legal principle, it is important to probe the roles that resilience serves as a guiding principle of law. Resilience needs to be examined deeply, not just instrumentally, as either a theory for legal practice as Prof RUHL argues, or merely as one among a collection of laws with relevance to unexpected change (eg as a part of disaster law ${ }^{121}$ ), or as occasional legal policies or legislative enactments that anticipate possible disruptions

118 JB RUHL, 'General Design Principles for Resilience and Adaptive Capacity in Legal Systems-With Applications to Climate Change Adaptation,' 89 N.C. L. Rev. 1373 (2011) $<$ http://scholarship.law.unc.edu/nclr/vol89/iss5/3>.

119 ibid 1400.

120 ibid 1402.

121 Daniel A FARBER and Michael G FAURE (eds), Disaster Law and Policy (Edward Elgar 2010). 
and seek to cope with their impacts (eg flood insurance laws ${ }^{122}$ ). Dr. Lia Helena DEMANGE makes a similar case in favour of recognizing resilience as a legal principle. ${ }^{123}$ As Prof Isabella MICHALLET ${ }^{124}$ has observed in her studies of laws to support the interests of future generations:

A more innovative solution is the principle of resilience, which would focus environmental action not on simply maintaining environmental stability, but on preserving ecosystem functions, providing the environment with the means to absorb anthropogenic disturbances and recover from them. One objective is to avoid irreversible situations in which an ecosystem becomes vulnerable to the point of losing its resilience. In that sense, the principle of resilience reinforces intergenerational equity ...

As a legal principle, resilience operates to guide governmental and other decision-making. That jurists have not yet closely studied the principle of resilience can perhaps be attributed to the fact that all of society largely accepts the reality of resilience and takes it for granted. However, once there is a deficit in resilience, as when a person experiences an accident or a severe storm causes harm, or an economic collapse is so deep that there can be no ready recovery, then the search for understanding and applying resilience as a general principle of law begins. Law has recognized other emerging principles in the past. For example, States acknowledged that the polluter pays principle existed once Henri SMETS advanced it through the Organization for Economic Development and Cooperation (OECD) in the 1970s. ${ }^{125}$ Today it is widely accepted. It came to be explicitly embraced when ambient pollution in the 196os and 1970 in North America and Europe had become vast, human health and the economy suffered, and polluters were escaping their responsibility. In like vein, the principle of resilience exists, but circumstances now compel its formal recognition.

The proposed Global Pact for the Environment sets forth the principle of resilience in Article 16: 'The Parties shall take necessary measures to maintain and restore the diversity and capacity of ecosystems and human communities

\footnotetext{
122 See, for example, the National Flood Insurance Program in the USA <https://www.naic .org/cipr_topics/topic_nfip.htm>.

123 Lia Helena Monteiro De Lima DEMANGE, The Principle of Resilience, 30 Pace Envtl. L. Rev. 695 (2013)<https://digitalcommons.pace.edu/pelr/vol3o/iss2/11>.

124 Isabelle MICHALLET, 'Equity and the Interests of Future Generations', Chapter vi.11 in KRÄMER and ORLANDO (n 83) 156.

125 See Henri SMETS, 'Environmental accidents: the polluter now pays', OECD Observer, no 160 , Oct.-Nov. 1989, 10.
} 
to withstand environmental disruptions and degradations and to recover and adapt.' This articulation has two dimensions. First, it recognizes that ecosystems and human communities have innate resilience that States, as Parties to the Pact, can and must respect and cultivate, and second, it assigns responsibility to States to maintain and restore this diverse capacity. It should be noted that in addition to States, every person, natural or legal, public or private, also has this duty, as the Pact observes generally in Article 2. All persons as well as governments can sustain resilience, to everyone's mutual benefit. ${ }^{126}$ The Principle promotes self-reliance and human foresight. Humans can anticipate and prepare for eventualities.

When invoking the principle of resilience, individuals would be empowered to propose that governments and other social enterprises act to make possible their recovery from disruptive events. Methodologies should be readied, and sustained, to facilitate socio-economic resilience. Preparing to foster resilience can be learned and enhanced. The techniques to do so are often self-evident. Historically, an early example for preparedness is the establishment of fire brigades and programs to prevent fires. ${ }^{127}$ The recent wildfires induced by climate change droughts from Australia to California to Portugal demonstrate that new applications of the principle of resilience are required. Moreover, many parts of the world still lack local capacity to prevent or extinguish fires and have no fire insurance programs. Many local human settlements lack building codes that prescribe construction in ways to avert or contain fires. Even where codes exist, corruption and a failure to enforce the standards effectively nullifies their purpose. Recognizing the principle of resilience could encourage, or even better, require governments to act to enhance resilience in their communities.

Such preparedness to enhance resilience is based on exercising foresight. The United Nations Sendai Framework for Disaster Risk Reduction is premised

126 Individual humans can cultivate resilience for themselves. See eg Paul BARTONE, 'Hardiness Resilience Gauge' at <https://www.mhs.com/MHS-Talent?prodname=HRG >. Medical education stresses the need to cultivate resilience in physicians; see <https:// wellmd.stanford.edu/healthy/resilience.html $>$. A heathy individual is a person that nurtures their resilience; see Harvard Health Letter 'Ramp up your resilience!' <https://www. health.harvard.edu/mind-and-mood/ramp-up-your-resilience >.

127 In 1254, by a royal decree King LOUIS authorized guet bourgeois ('burgess watch'), allowing the residents of Paris to establish their own night watches, separate from the king's night watches, to prevent and stop fires. The Paris Fire Brigade began in the 170os. In 1736, in Philadelphia Benjamin FRANKLIN established the Union Fire Company. World-wide, there are examples of local firefighting units. In time, insurance systems also came to be established to provide funds to recover and rebuild after fires. 
on fostering resilience. ${ }^{128}$ In this State practice, resilience emerges as a most significant foundation for the framework for international cooperation for coping with disasters. This focus is the manifestation of resilience as a general principle of law being applied.

Other instances of respecting the principle of resilience are found in measures to provide back-up systems and redundancies, in order to ensure that essential services or activities can continue despite disruption. For example, hospitals routinely have electric generators that allow medical care to continue when the centrally supplied systems of electricity are disrupted. Economic theory often encourages 'last minute' production to maximize profits or achieve cost-savings by avoiding stock-piling materials or goods, but these practices leave essential supply chains at risk to disruptions. Recognizing the principle of resilience tempers excessively efficient economic judgments and encourages more sustainable practices. For instance, in 2011, flood waters inundated Bangkok, and supplies of computer chips and other equipment manufactured there as a contribution to assembling commercial products on a transnational basis were disrupted acutely. ${ }^{129}$

When States acknowledge the principle of resilience, they are likely to take measures necessary to provide for social, ecological and economic resiliencies. When they neglect that principle, they leave their people at risk. Resilience is found in ecology and in humans, and has a place as a principle in ecological law. Today, when risks from climate disruption are seen to abound and increase, it is in the self-interest of all persons, governments, economic enterprises, and all other undertakings to embrace the principle of resilience. Strengthening resilience bolsters other measures to implement the SDGs, and to enhance the implementation of the other fundamental principles. The principle of resilience is thus a basic norm for our times. How should this principle be expressed as a norm in the context of attaining an ecological civilization? Perhaps the most important benefit of States recognizing the principle of resilience will be the guidance they provide for their citizens to adapt and be ready to again bounce back on a firmer footing during times of ecological disruption.

128 The Sendai Framework provides for international cooperation in four priority dimensions, which illustrate the practical benefits of respect for fostering Resilience: Understanding disaster risk; Strengthening disaster risk governance to manage disaster risk: Investing in disaster risk reduction for resilience; Enhancing disaster preparedness for effective response and to 'Build Back Better' in recovery, rehabilitation and reconstruction; see $<$ https://www.undrr.org/implementing-sf $>$.

129 Shara TIPKIN, ‘Thai Floods Jolt PC Supply Chain', Wall Street Journal (October 18, 2011). 


\section{Conclusion: the Continuing Quest for Ecological Law Principles}

This article has sought to illustrate how the principles of ecological civilization could help shape a consensus about restating environmental legal principles generally. This restatement is essential as human laws have proven to be manifestly at variance with the natural systems of Earth's biosphere. Disruptions caused by climate change increase and the sixth great extinction of species ushers in biodiversity crises. As humans continue an assault on Earth's environment, it is evident that adopting Agenda 21, the Rio Declaration, the Johannesburg Declaration ${ }^{130}$ and the Sustainable Development Goals have been necessary, but not sufficient, steps. While each is progressive, they have not yet integrated environmental protection with social and economic goals (the three pillars of sustainable development). Further steps are needed.

As proponents of ecological law explain, one cannot fill the gaps in international environmental law because the premise is flawed. Human laws first must be grounded in the laws of nature, of ecology. While environmental law continues to be based on the laws of humans manipulating nature. there will inevitably be gaps and shortcomings. It was argued that norms of ecological civilization can contribute principles of law that build a reciprocity between the human species and all other species and ecosystems. New environmental principles will need to be added to the existing ones. Some emerging new principles, which have been taken for granted, will need to be cultivated, and none more so than the principle of resilience. At the heart of this principle is the goal of helping living beings and ecological systems respond to change by recovering and restoring previous capabilities and adapting or evolving anew to a sustainable status. The environment must be provided with the means to absorb anthropogenic disturbances and recover from them.

Globally, human interdependence on the hydrologic cycle means that we are all stakeholders in managing Earth's waters, soils, mountains, flora and fauna. Nature is resilient, and can inspire resilience in each human being. We share Earth's biosphere together, and have reciprocal rights and duties for stewardship of ecosystems. As law progresses from environmental law to ecological law, we need to agree on its core legal principles. Ultimately is it not our shared appreciation of Earth's beauty, its landscapes and the community of life, that motivates us to do our duty, to the planet and each other? China can contribute greatly to the global debate about Earth's ecological principles of law by sharing its knowledge and understanding of its increasingly accepted concept of ecological civilization; but to attain it, we all need to cooperate together.

130 Johannesburg Declaration on Sustainable Development, A/REs/69/216. 